\title{
Properties of Particleboard Made from Oil Palm Trunks Added Magnesium Oxide as Fire Retardant
}

\author{
Mohd Ezwan Selamat, Teh Yun Hui, Rokiah Hashim, Othman Sulaiman,* \\ Mohamad Haafiz Mohamad Kassim and Natra Joseph Stalin \\ Division of Bioresource, Paper and Coatings Technology, School of Industrial \\ Technology, Universiti Sains Malaysia, 11800 USM Pulau Pinang, Malaysia \\ "Corresponding author: osulaiman@gmail.com
}

Published online: 25 April 2018

To cite this article: Selamat, M. E. et al. (2018). Properties of particleboard made from oil palm trunks added magnesium oxide as fire retardant. J. Phys. Sci., 29(1), 59-75, https://doi.org/10.21315/jps2018.29.1.5

To link to this article: https://doi.org/10.21315/jps2018.29.1.5

\begin{abstract}
The aim of this study is to evaluate the physical, mechanical and flame retardant properties of particleboard made from oil palm trunk (OPT) with the addition of magnesium oxide as flame retardant. The physical and mechanical properties of the particleboard were evaluated based on Japanese Industrial Standard (JIS A 5908) and the flame retardant properties were determined according to International Standards Organization (ISO 4589). The particleboard was manufactured to a target density $0.80 \mathrm{~g} \mathrm{~cm}^{-3}$ with addition of magnesium oxide $(0 \%, 10 \%$ and 20\%). The results showed the thickness swelling and water absorption of treated particleboard decreased as the percentage of magnesium oxide increased. The untreated OPT particleboard without any flame retardant showed better mechanical strength. For thermogravimetric analysis (TGA), the treated OPT particleboard showed better thermal stability compared with the untreated OPT particleboard. The OPT particleboard treated with 20\% magnesium oxide showed better flame retardant properties compared to the control and 10\% magnesium oxide sample that satisfied the ISO 4589 standard requirement.
\end{abstract}

Keywords: Physical properties, mechanical properties, flame retardant, oil palm trunk, magnesium oxide

\section{INTRODUCTION}

Particleboard is one of the engineered panels invented in the 19th century, but started to be commercialised in 1940s as a replacement for plywood due to shortage of lumber in plywood manufacturing. ${ }^{1}$ It is usually made from a mixture of particles 
bonded together with binder resin and some of the additives and then mechanically pressed into sheet form. ${ }^{2}$ Due to the high demand of particleboards, it is necessary to manufacture ones that are more cost effective. Due to the material's abundance in quantity, relatively more cost effective than wood, and lower manufacturing cost, agricultural crop byproducts are a wise choice to manufacture particleboard. ${ }^{3}$

Malaysia is one of the world's largest producers and exporters of palm oil, with 5.64 million hectares of oil palm plantation recorded in 2015.,5 Besides producing a large amount of palm oil, it also produces a large amount of agricultural wastes such as oil palm fronds (OPF), empty fruit bunches (EFB), oil palm trunk (OPT), palm pressed fibres (PPF), palm oil mill effluent (POME) and palm shells. ${ }^{6}$ If these wastes are not disposed well, the consequence will negatively impact the environment. To overcome this problem, the utilisation of oil palm tree to produce a variety of valuable products has been done in numerous studies. The productions of nanocrystalline cellulose (NCC), microcrystalline cellulose (MCC) and bio char proved that besides oil, oil palm tree also can be used as the main raw materials to produce other products for different applications. ${ }^{7-10}$

The production of particleboard with fire resistant properties is very important to ensure that occupants may safely evacuate, loss of property may be minimised, and firemen may extinguish the fire effectively. Yet, so far no wood material is completely fireproof; only limited fire resistance can be achieved in wood. ${ }^{11}$ Flame retardants are chemical substances that are added to materials in order to inhibit or delay the spread of fire as well as to stop the polymer combustion process. ${ }^{4}$ There are many types of flame retardant chemicals such as halogen-based, halogen-free and metal oxide-hydroxide minerals. ${ }^{12}$ Table 1 shows the previous studies that investigated the effectiveness of flame retardant treatments on wood composites.

All these factors are reasons for the selection of raw materials and fire retardant. Previous study by Chin showed that different types of urea formaldehyde (UF) resin will give different effect especially on the physical and mechanical properties of the particleboard. ${ }^{1}$ However, there is no study on the effect of OPT particleboard bonded with UF resin and magnesium oxide as additive. Although some commercial panel products such as XinLongBoard and RockMax use magnesium oxide filled with palm fibre as filler to produced fire retardant panels, the main different between these commercial products with the one produced in this study is magnesium oxide was added to reinforced and improved the flame retardant properties of OPT particleboard. ${ }^{11,12}$ 
Table 1: Flame retardants of various wood composites.

\begin{tabular}{|c|c|c|c|c|}
\hline Board & Materials & Adhesives & Additives & Authors \\
\hline Particleboard & $\begin{array}{l}\text { Oak (Quercus } \\
\text { spp.), lauan } \\
\text { (Shorea spp.) }\end{array}$ & $\begin{array}{l}\text { Polymeric } \\
4,4^{\prime} \text {-methylenediphenyl } \\
\text { isocyanate (PMDI), } \\
\text { Phenol formaldehyde } \\
\text { (PF) }\end{array}$ & $\begin{array}{l}\text { FR1: Mixture of ammonium } \\
\text { phosphate, diammonium } \\
\text { phosphate, ammonium } \\
\text { sulphate, borax, boric acid, } \\
\text { ammonium bromide } \\
\text { FR2: Mixture of chloride, } \\
\text { inflammable emulsion resin, } \\
\text { phosphide, titan white, and } \\
\text { other volatile components }\end{array}$ & $\begin{array}{l}\text { Wang et al. } \\
(2008)\end{array}$ \\
\hline $\begin{array}{l}\text { Medium density } \\
\text { fibreboard }\end{array}$ & $\begin{array}{l}\text { Rubberwood } \\
\text { fibres }\end{array}$ & UF & $\begin{array}{l}\text { Sodium aluminate, zinc } \\
\text { borate, aluminium trihydrate } \\
\text { (ATH) }\end{array}$ & $\begin{array}{l}\text { Hashim et al } \\
(2009)\end{array}$ \\
\hline Particleboard & Kenaf & UF & $\begin{array}{l}\text { Diammonium phosphate } \\
\text { (DAP) }\end{array}$ & $\begin{array}{l}\text { Kamal et al. } \\
(2009)\end{array}$ \\
\hline Particleboard & Kenaf & UF & $\begin{array}{l}\text { Monoammonium phosphate } \\
\text { (MAP) }\end{array}$ & $\begin{array}{l}\text { Thinnizir } \\
\text { et al. (2009) }\end{array}$ \\
\hline Particleboard & Kenaf & UF & $\begin{array}{l}\text { Mixture of boric acid (BA), } \\
\text { guanylurea phosphate, and } \\
\text { phosphoric acid }\end{array}$ & $\begin{array}{l}\text { Izran et al. } \\
(2010)\end{array}$ \\
\hline Particleboard & $\begin{array}{l}\text { Engkabang, } \\
\text { acacia mangium }\end{array}$ & UF & $\begin{array}{l}\text { Zinc borate, } \\
\text { monoammonium phosphate }\end{array}$ & $\begin{array}{l}\text { Kamal et al. } \\
(2010)\end{array}$ \\
\hline Particleboard & Rubberwood & UF & $\begin{array}{l}\text { Combine phosphoric acid } \\
\text { and BA }\end{array}$ & $\begin{array}{l}\text { Izran et al. } \\
(2011)\end{array}$ \\
\hline Particleboard & Saw dust fibres & UF & BA, borax (BX) & $\begin{array}{l}\text { Nagieb et al. } \\
\text { (2011) }\end{array}$ \\
\hline Particleboard & White birch & UF & BA & $\begin{array}{l}\text { Pedieu et al. } \\
(2012)\end{array}$ \\
\hline $\begin{array}{l}\text { Natural fibre- } \\
\text { reinforced } \\
\text { composite }\end{array}$ & EFB, kenaf & $\begin{array}{l}\text { Polylactic acid (PLA), } \\
\text { polystyrene (PS), epoxy } \\
\text { resin }\end{array}$ & ATH & $\begin{array}{l}\text { Tshai et al. } \\
\text { (2014) }\end{array}$ \\
\hline
\end{tabular}

*FR: Flame retardant

In this study, the OPT particles were used as the main material while the commercial panels are using the palm fibre as filler. In addition, the commercial panels as previously mentioned are using magnesium oxide as the main material to form the matrix of the panels. In this study, the physical, mechanical and thermal properties of the flame retardant oil palm trunk particleboard were investigated. 


\section{EXPERIMENTAL}

\subsection{Particleboard Manufacturing}

OPT particles were used as raw material and were obtained from Encore Agricultural Industries Sdn. Bhd., Pahang, Malaysia. The UF resin used as binder for this study was obtained from Asta Chemicals located in Perai, Penang, Malaysia. Flame retardant additive used in this research was magnesium oxide $(\mathrm{MgO})$ powder whereas ammonium chloride $\left(\mathrm{NH}_{4} \mathrm{Cl}\right)$ was used as hardener.

Initially, the OPT particles were dried in an oven at $103 \pm 2^{\circ} \mathrm{C}$ for $2 \mathrm{~h}$ to ensure that the moisture content of the particles was between $4 \%$ and $6 \%$. The particleboard was produced to a target density of $0.80 \mathrm{~g} \mathrm{~cm}^{-3}$ with 6 replicates of particleboards for each set to ensure the collected data is more accurate. About $10 \%$ of UF, magnesium oxide (10\% and $20 \%)$ and $1 \%$ of ammonium chloride based on oven dried weight of OPT particles were mixed manually with hand and stirred with $20 \mathrm{ml}$ of distilled water. The addition of distilled water is to ensure that the UF resin is uniformly distributed within the particles since only $10 \%$ of UF resin was added into the mixture. The mixture was then placed into a mold with dimensions of $21.0 \mathrm{~cm} \times 21.0 \mathrm{~cm} \times 0.5 \mathrm{~cm}$, followed by a pre-pressing using a cold press machine to form a mat. The mat was then hot pressed at a temperature of $160^{\circ} \mathrm{C}$ with a pressure of $40.0 \mathrm{MPa}$ for $8 \mathrm{~min}$. The particleboard was cooled and conditioned in a room with surrounding temperature of $25 \pm 2{ }^{\circ} \mathrm{C}$ and a relative humidity of $65 \pm 2 \%$ for 2 days. Particleboard prepared without the addition of magnesium oxide was used as control particleboard to determine the effect of magnesium oxide on the particleboard properties.

\subsection{Determination of $\mathrm{pH}$ of Oil Palm Trunk Particles}

The $\mathrm{pH}$ of oil palm particles was determined according to the method described by Lebow and Winandy. ${ }^{15}$ Approximately $1 \mathrm{~g}$ of samples was mixed with $20 \mathrm{ml}$ of distilled water and soaked at room temperature overnight. The $\mathrm{pH}$ meter (Mettler Toledo) was used to measure the $\mathrm{pH}$ values of untreated and treated particles.

\subsection{Evaluation of Physical and Mechanical Properties}

The physical and mechanical tests were carried out according to Japanese Industrial Standard (JIS A 5908). ${ }^{16}$ The physical tests consist of density, moisture content, water absorption and thickness swelling. For mechanical testing, the modulus of rupture (MOR), modulus of elasticity (MOE) and internal bond (IB) were carried out using an Instron Tensile Machine Model 5582. 


\subsection{Characterisation of Particleboard}

\subsubsection{FTIR analysis}

The Fourier transform infrared (FTIR) spectroscopy was used to identify any major difference in presence of functional groups between control sample and samples with magnesium oxide additive of particleboard. In this test, Nicolet Avatar 360 ESP FTIR spectrophotometer was used to analyse each material.

\subsubsection{SEM analysis}

Scanning electron microscopy (SEM) was used to observe morphological properties and bonding quality of raw material and UF resin with different concentration of magnesium oxide on panels produced. The samples were examined using SEM microscope LEO Model Supra 50 Vp, Carl Ziess SMT, Germany with an accelerating voltage of $15 \mathrm{kV}$.

\subsubsection{EDX analysis}

The samples used for SEM analysis was then further extended to determine the elemental composition of raw materials by energy dispersive X-ray (EDX) analysis. The instrument used was Oxford INCA 400 energy dispersive X-ray microanalysis system (Oxford Instruments Analytical, Bucks, UK).

\subsubsection{XRD analysis}

The X-ray diffractometry (XRD) was used to determine the percentage of crystalline structure. The instrument used in this test was a Kristal-loflexD-5000 X-ray diffraction system (Siemens, Germany). The X-rays $(\mathrm{Cu})$ were generated with an opening voltage of $40 \mathrm{kV}$ and a current of $30 \mathrm{~mA}$ for the step scan measurement. The scanning process was then carried out at a $2 \theta$ diffraction angle in the range of 10-40 with 0.02 and $2 \mathrm{~min}^{-1}$ scanning speed. The crystallinity index of each sample was determined using the same formula used by Segal et al. ${ }^{17}$ as shown in Equation 1:

$$
\mathrm{C}_{\mathrm{ir}}(\%)=\frac{\mathrm{I}_{200}-\mathrm{I}_{\mathrm{am}}}{\mathrm{I}_{200}} \times 100
$$

where

$\mathrm{I}_{200}=$ peak intensity of crystalline fraction

$I_{\mathrm{am}}=$ peak intensity of amorphous fraction 


\subsection{Thermal Analysis and Flame-retardant Properties of Particleboard}

\subsubsection{TGA}

Thermogravimetric analysis (TGA) was used to determine properties of materials such as mass changes as they change with temperature and study thermal degradation reactions of materials. ${ }^{17}$ In this test, a Mettler Toledo TGA/ SDTA85 thermogravimeter (Mettle Toledo Corp., Switzerland) with STA software (version 9.20) was used to characterise all 3 samples. ${ }^{18}$ Each sample was subjected to the increased heat with $20^{\circ} \mathrm{C} \mathrm{min}^{-1}$ heating rate starts from $30 \pm 2^{\circ} \mathrm{C}$ up to $800 \pm 2{ }^{\circ} \mathrm{C}$.

\subsubsection{LOI}

Limiting oxygen index (LOI) was used to determine the flammability of materials treated with flame retardant chemicals. For this test, 5 replicates with $8 \mathrm{~cm} \times 1 \mathrm{~cm}$ dimensions from each condition was analysed according to the ISO 4589 with the Fire Testing Technology LOI instrument. ${ }^{19}$

\section{RESULTS AND DISCUSSION}

\section{1 pH Value of Oil Palm Trunk Particles}

The $\mathrm{pH}$ values of particles before and after treatments ranged between 6.33 and 10.20. OPT particles had the $\mathrm{pH}$ value of 6.33 which is considered as weak acid. The board treated with $10 \%$ magnesium oxide showed high alkalinity with 10.12 while 10.20 for particleboard treated with $20 \%$ magnesium oxide respectively. This is because magnesium oxide is a basic oxide that will give alkali properties to the produced board. The $\mathrm{pH}$ of the particles basically will affect the physical and mechanical properties of the particleboard produced. ${ }^{20}$ Previous study by Yusoff et al. showed that the properties of fibre used in the production of particleboard decreased after the fibre was treated with sodium hydroxide, $\mathrm{NaOH}$ which is an alkaline base. ${ }^{21}$

\subsection{Physical Properties}

The physical properties of particleboards were shown in Table 2. The average density value for all particleboards produced was not much different with a target density of $0.80 \mathrm{~g} \mathrm{~cm}^{-3}$. This is because same mould was used to produce each of particleboard in the laboratory. All of the OPT particleboards produced also had met the standard requirement stated in the Japanese Industrial Standard (JIS A $5908)^{16}$ which was in the range of $0.40 \mathrm{~g} \mathrm{~cm}^{-3}$ to $0.90 \mathrm{~g} \mathrm{~cm}^{-3}$. Moisture content 
for the particleboards produced showed decreasing trend as the percentage of magnesium oxide increased and ranged at 3\%-6\%. For thickness swelling after $24 \mathrm{~h}$, the OPT particleboard treated with $20 \%$ magnesium oxide showed the lowest thickness swell compared to untreated and particleboard treated with $10 \%$ magnesium oxide. The results for water absorption correspond well with thickness swelling. As the loading of flame retardant increased, water absorption and thickness swelling decreased. During the production of particleboard, some fire retardant additives were probably able to penetrate into the oil palm trunk particles in order to hinder water absorption of the samples. This can be seen in Figure 1 showing crystals of flame retardant additives on cell wall of particles.

Table 2: The physical (a) and mechanical (b) properties of control sample and particleboard added with magnesium oxide.

\begin{tabular}{|c|c|c|c|c|c|c|c|c|c|}
\hline \multirow{2}{*}{ Sample } & \multirow{2}{*}{$\begin{array}{l}\text { Density } \\
\left(\mathrm{g} \mathrm{cm}^{-3}\right)\end{array}$} & \multirow{2}{*}{$\begin{array}{c}\text { Moisture } \\
\text { content } \\
(\%)\end{array}$} & \multicolumn{2}{|c|}{$\begin{array}{c}\text { Water absorption } \\
(\%)\end{array}$} & \multicolumn{2}{|c|}{$\begin{array}{c}\text { Thickness swelling } \\
(\%)\end{array}$} & \multirow{2}{*}{$\begin{array}{l}\text { MOR } \\
(\mathrm{MPa})\end{array}$} & \multirow{2}{*}{$\begin{array}{c}\text { MOE } \\
(\mathrm{MPa})\end{array}$} & \multirow{2}{*}{$\begin{array}{c}\text { IBS } \\
(\mathrm{MPa})\end{array}$} \\
\hline & & & $2 \mathrm{~h}$ & $24 \mathrm{~h}$ & $2 \mathrm{~h}$ & $24 \mathrm{~h}$ & & & \\
\hline $\begin{array}{l}\text { Control } \\
\text { sample }\end{array}$ & $\begin{array}{c}0.81 \\
(0.03)\end{array}$ & $\begin{array}{c}5.57 \\
(0.22)\end{array}$ & $\begin{array}{l}91.61 \\
(6.32)\end{array}$ & $\begin{array}{l}118.01 \\
(6.86)\end{array}$ & $\begin{array}{l}34.22 \\
(6.11)\end{array}$ & $\begin{array}{l}41.45 \\
(8.64)\end{array}$ & $\begin{array}{c}5.80 \\
(1.33)\end{array}$ & $\begin{array}{l}1149.60 \\
(185.73)\end{array}$ & $\begin{array}{l}1.16 \\
(0.75)\end{array}$ \\
\hline $\begin{array}{l}10 \% \\
\mathrm{MgO}\end{array}$ & $\begin{array}{c}0.81 \\
(0.06)\end{array}$ & $\begin{array}{l}4.75 \\
(0.16)\end{array}$ & $\begin{array}{l}88.67 \\
(8.12)\end{array}$ & $\begin{array}{l}99.92 \\
(7.26)\end{array}$ & $\begin{array}{l}31.44 \\
(6.14)\end{array}$ & $\begin{array}{l}38.51 \\
(7.36)\end{array}$ & $\begin{array}{c}4.30 \\
(1.31)\end{array}$ & $\begin{array}{c}848.40 \\
(161.03)\end{array}$ & $\begin{array}{c}0.62 \\
(0.44)\end{array}$ \\
\hline $\begin{array}{l}20 \% \\
\mathrm{MgO}\end{array}$ & $\begin{array}{c}0.80 \\
(0.04)\end{array}$ & $\begin{array}{c}3.92 \\
(0.14)\end{array}$ & $\begin{array}{l}77.71 \\
(7.42)\end{array}$ & $\begin{array}{l}85.70 \\
(7.56)\end{array}$ & $\begin{array}{l}20.91 \\
(5.77)\end{array}$ & $\begin{array}{l}28.83 \\
(6.95)\end{array}$ & $\begin{array}{c}2.90 \\
(1.06)\end{array}$ & $\begin{array}{c}786.60 \\
(145.50)\end{array}$ & $\begin{array}{c}0.54 \\
(0.23)\end{array}$ \\
\hline
\end{tabular}

Notes:

$M O R=$ Bending strength,$M O E=$ Bending modulus, IBS = Internal bond strength

*10\% MgO: Particleboard mixed with 10\% magnesium oxide

*20\% MgO: Particleboard mixed with 20\% magnesium oxide

*Values in parentheses represent the standard deviation

\subsection{Mechanical Properties}

The results of mechanical properties for all the particleboards produced were shown in Table 2. Based on Table 2, the collected data for mechanical properties showed similar trend as the physical properties. It shows the decreasing trend for MOR, MOE and IBS of OPT particleboards as the percentage of flame retardant additive increased. The control samples which are free from any flame retardant showed the highest average reading for all three mechanical tests. The OPT particleboard added with $20 \%$ magnesium oxide gives the lowest average reading MOR, MOE as well as IBS. This might be due to the presence of flame retardant additives deposited on the particles of OPT particleboards as indicated by the SEM analysis (Figure 2). The deposited of flame retardant in particleboard probably will interfere the inter-particle bonding between the particles that will weaken the mechanical strength of the particleboard. 


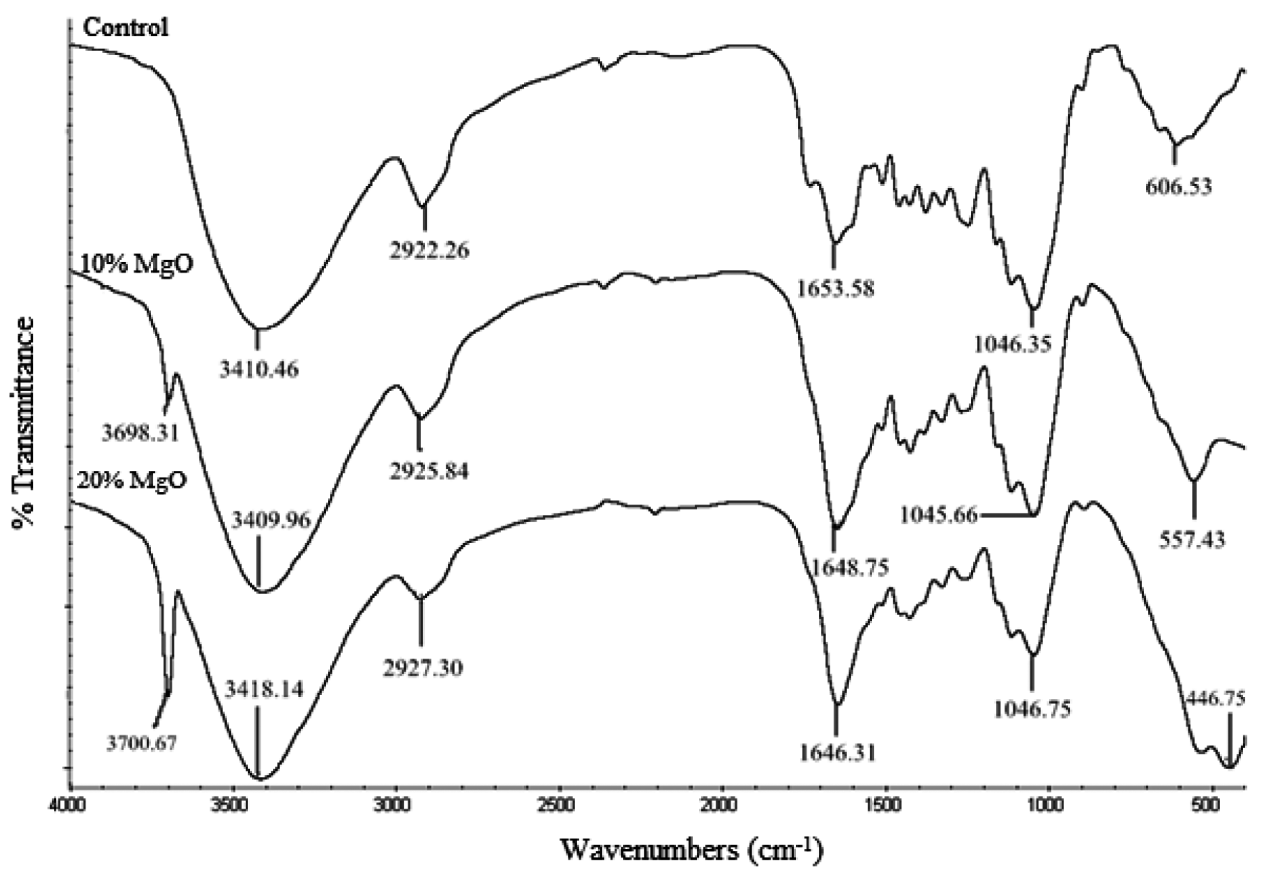

Figure 1: FTIR spectrum for control sample and particleboards treated with different loading of magnesium oxide.

\subsection{Characterisation of Particleboard}

\subsubsection{FTIR analysis}

This analysis was conducted to obtain a clear view of OPT particleboard before and after treated with magnesium oxide and to determine the existence of any new functional groups. The results of FTIR are shown in Figure 1. There was not much difference in spectra for all the particleboards produced. The significant different was at the peak around $4000-3500 \mathrm{~cm}^{-1}$ for all the OPT particleboards produced. It was obvious that only OPT particleboard treated with $10 \%$ and $20 \%$ magnesium oxide had the peak which was $3698.31 \mathrm{~cm}^{-1}$ and $3700.67 \mathrm{~cm}^{-1}$ respectively. This may be caused by the presence of stretching $\mathrm{O}-\mathrm{H}$ groups that form after the reaction between magnesium oxide and water during particleboard making. ${ }^{21}$

\subsubsection{SEM analysis}

This analysis was carried out to observe the distribution of adhesive and additive in the OPT particleboard produced. Figure 2 (a) and (b) with 500X and 1000X magnification showed that UF resin are well mixed with particles on both samples. 
With larger 1000X magnification for Figure 2(a), the clear view of silica was observed in untreated OPT particleboard sample which is similar to the previous finding by Darmawan et al. ${ }^{22}$ The natural presence of silica in OPT particles could help to improve the flame retardant properties but at the same time may decrease the physical and mechanical properties of the prepared particleboard. ${ }^{23}$ In Figure 2(b) with 1000X magnification, the presence of round shape magnesium oxide was observed scattered on the particles surface. The magnesium oxide observed in this study is supported by Tamilselvi et al. finding where it showed similar shape of magnesium oxide. ${ }^{24}$
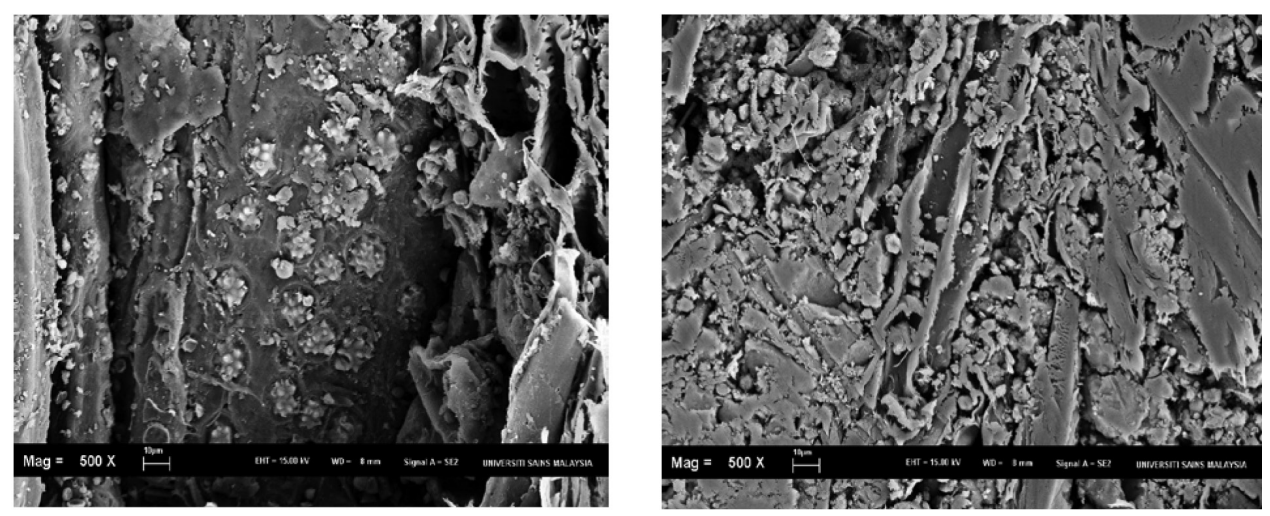

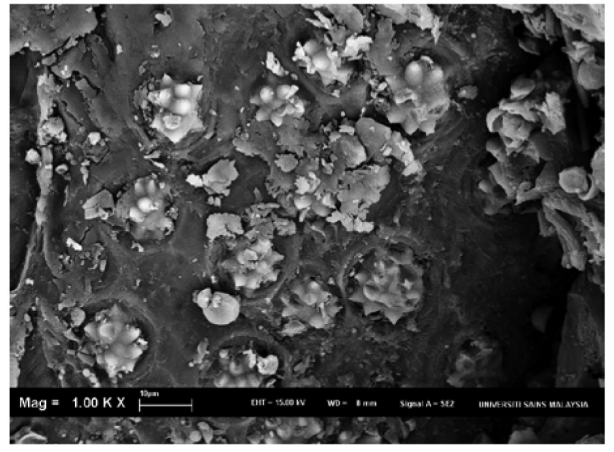

(a)

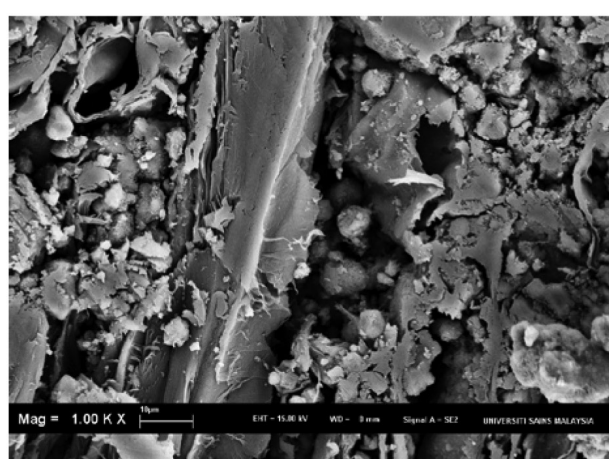

(b)

Figure 2: SEM micrograph of cross sectional view of (a) untreated OPT particleboard, and (b) OPT particleboard treated with $20 \%$ magnesium oxide (magnification $=$ $500 \mathrm{X}$ and 1000X).

\subsubsection{EDX analysis}

EDX was used to analyse the elemental composition of flame retardant OPT particleboard compared to control sample. The results obtained in EDX (Figure 3) can be used to prove the results obtained in SEM analysis. From Figure 3, it can 
be seen that control sample contained carbon $(\mathrm{C})$, silica $(\mathrm{Si})$ and oxygen $(\mathrm{O})$. The highest percentage of element detected in control sample is oxygen with $72.29 \%$ followed by carbon with $26.71 \%$. About $1 \%$ of silica was recorded in this sample and it is supported by previous SEM analysis that the presence of crystal-like structure in control sample. This $1 \%$ of silica is natural silica from the OPT particle that could help to improve the flame retardant properties of the particleboard. ${ }^{25}$ In the OPT particleboard treated with $20 \%$ magnesium oxide, about $60.14 \%$ of oxygen, $22.96 \%$ of magnesium and $16.90 \%$ of carbon was recorded. High percentages of magnesium in this sample is due to high amount of flame retardant.

The percentage of carbon and oxygen decreased as the percentage of magnesium oxide increased as indicated in Figure 3. High loading of magnesium oxide added is the main reason that lead to the increase of magnesium (22.96\%). Furthermore, high percentage of magnesium oxide detected in this analysis also indicates that the OPT particles are well mixed with the flame retardant.

\subsubsection{XRD analysis}

This analysis was conducted to determine the crystallinity of crystal structure and lattice constant of OPT particles before and after the particleboard making. As presented in Figure 4, there are no major differences in crystallinity index before and after the production of particleboard. However, there is a slight change detected in the OPT particleboard treated with $10 \%$ magnesium oxide with $58.7 \%$ compared to the OPT particles with $58.0 \%$. The control sample which is free from addition of flame retardant gives $54.9 \%$. Moreover, the crystallinity index of control OPT particleboard showed lower reading than the treated particleboard with $54.9 \%$. This is due to the addition of magnesium oxide that deposited on the particles. In addition, the effect of treated OPT particleboard is supported by the SEM and EDX analysis as previously discussed.

\subsection{Thermal Analysis and Flame Retardant Properties}

\subsubsection{TGA analysis}

This analysis is to study thermal degradation and to determine properties of materials as the temperature changes. ${ }^{26,27}$ In this study, the decomposition of OPT particleboard with three different conditions was evaluated. The control sample was used as relative to the effectiveness of the OPT particleboard treated with magnesium oxide. ${ }^{28}$ Based on Figure 5(a), three stages of weight loss were observed on each sample. 


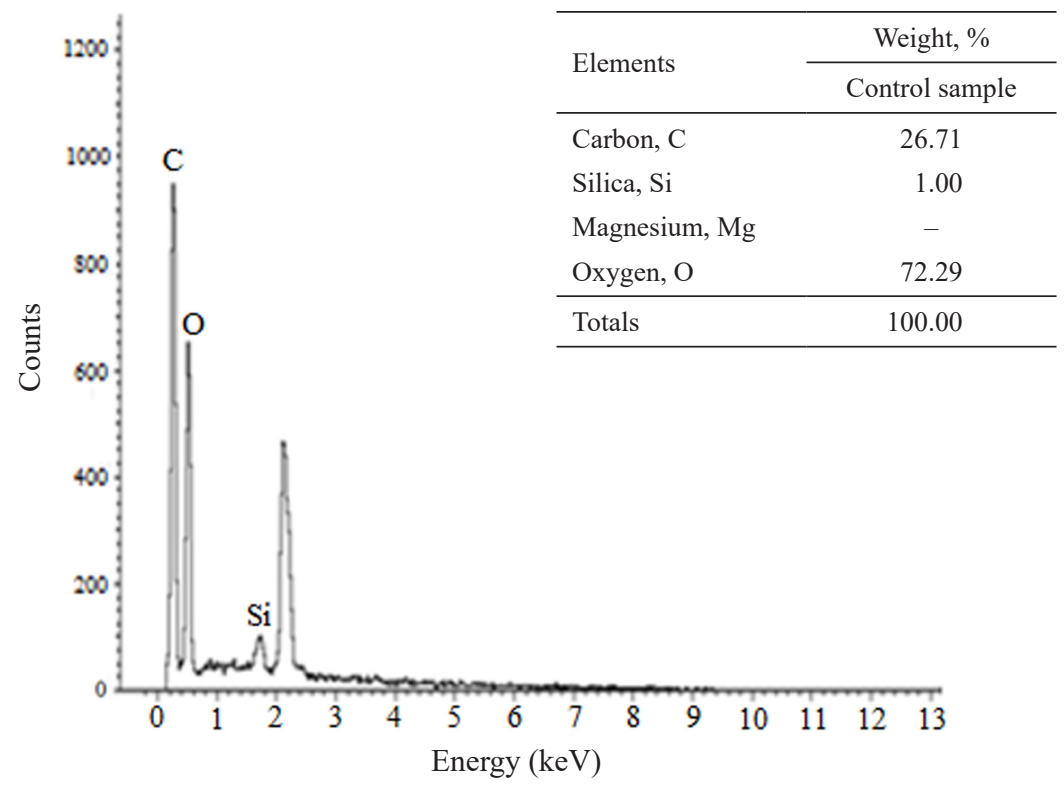

(a)

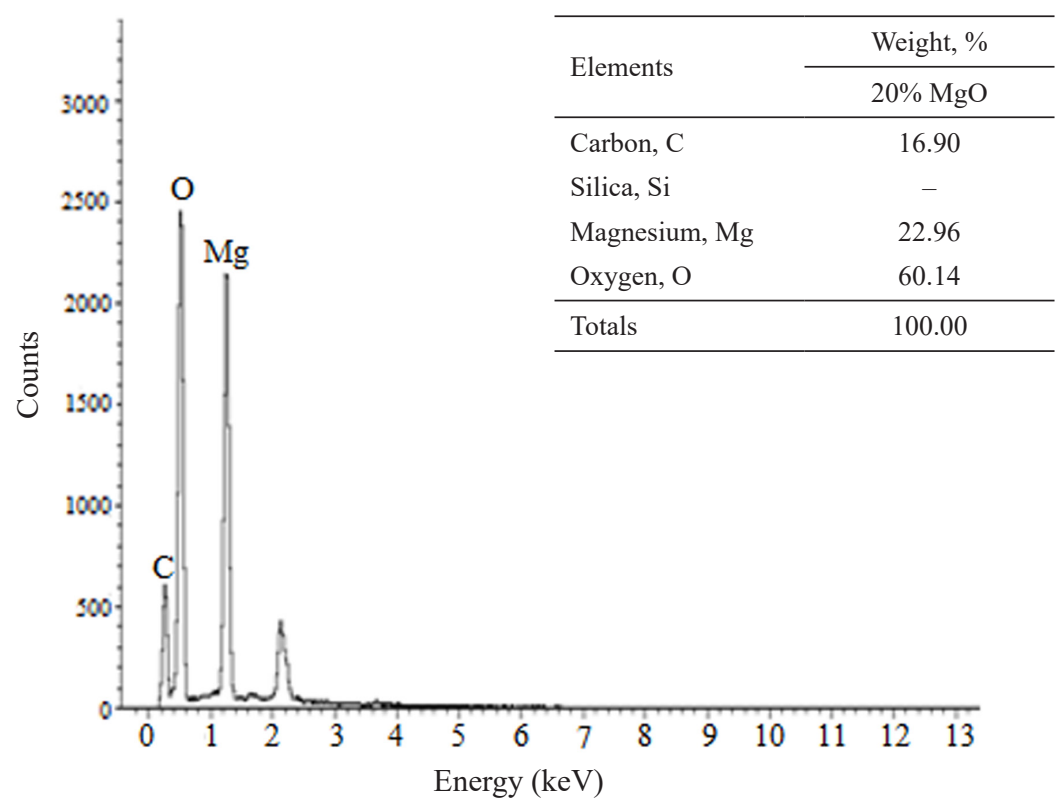

(b)

Figure 3: SEM micrograph and EDX spectrum of OPT particleboard of (a) untreated OPT particleboard, (b) OPT particleboard treated with 20\% magnesium oxide. 


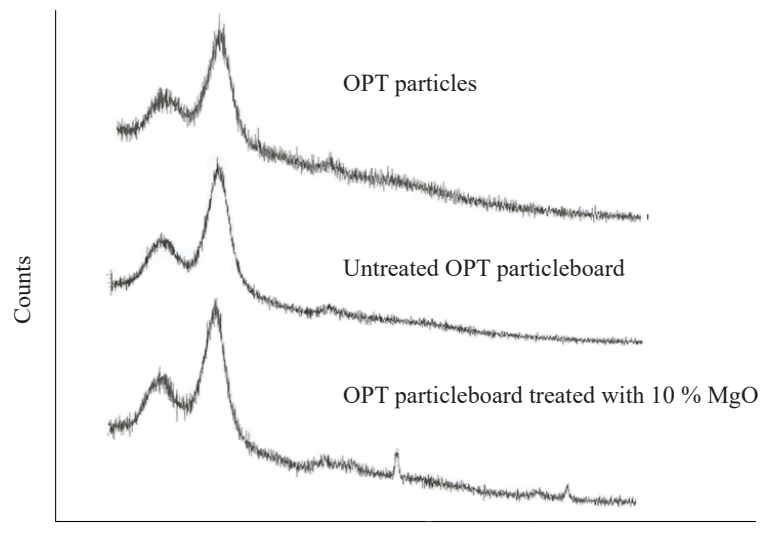

2 Theta (Couple Two Theta/Theta) WL $=1.54060$

Figure 4: XRD of OPT particle and particleboard prepared.

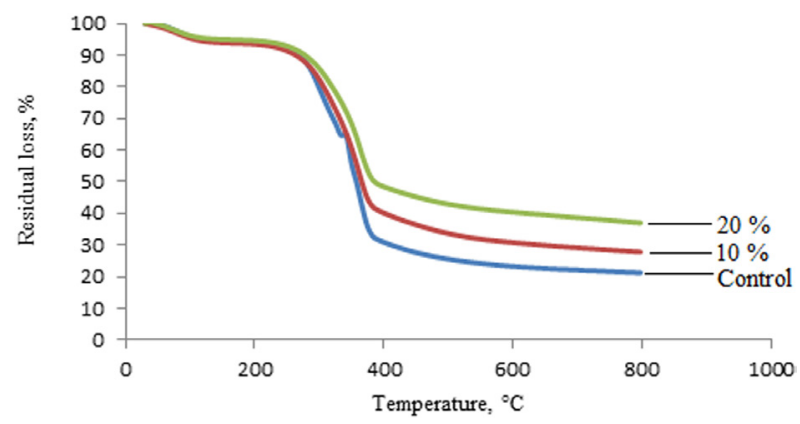

(a)

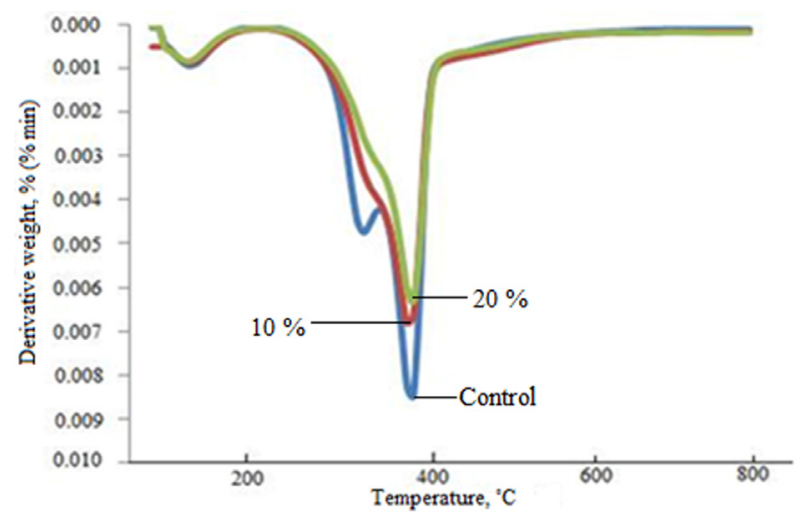

(b)

Figure 5: Illustrations of (a) TG and (b) DTG curves of OPT particleboards treated with different percentage of magnesium oxide compared to control sample. 
The initial weight loss took place due to the drying and evaporation of moisture and other volatile materials from $50^{\circ} \mathrm{C}$ to $150^{\circ} \mathrm{C}$. The second stage of weight loss is caused by the degradation of non-celluloses materials such as hemicelluloses ranging from $150^{\circ} \mathrm{C}$ to $300^{\circ} \mathrm{C}$. In addition, it also represents the breakage of glycosidic bond in the sample. In second stage, the percentage of weight residue for the particleboard treated with magnesium oxide showed almost similar results with $73.21 \%$ for $10 \%$ magnesium oxide treated particleboard and $73.40 \%$ for particleboard treated with $20 \%$ magnesium oxide whereas, the control particleboard sample gives the lowest residue with $68.95 \%$. The third stage or final stage of weight loss for all sample occurred in the range $300^{\circ} \mathrm{C}$ to $380^{\circ} \mathrm{C}$. The degradation and depolymerisation of $\alpha$-celluloses in the samples took placed in this stage. ${ }^{29}$ At the end of this analysis, the highest percentage of residue was observed in particleboard treated with $20 \%$ magnesium oxide with $43.08 \%$ followed with the $10 \%$ treated particleboard with $27.90 \%$ and control sample with $21.34 \%$.

From this analysis, it is proven that the addition of magnesium oxide successfully improved the thermal stability of the sample. An increase in the percentage of flame retardant showed higher percentage of residue. This is because magnesium oxide acts as a good insulating barrier capable of resisting the heat. ${ }^{30}$ Although the control OPT particleboard samples contain silica, it is not good enough to overcome the high temperature exposed on it producing low residue than other samples. The magnesium oxide provides a protective region in the particleboard that enables it to prevent thermal degradation of the sample. Previous study by Tay et al. stated that as the amount of flame retardant increase, the degradation temperature increase, and the mass residue will also increase. ${ }^{31}$

From the results obtained, it has been confirmed that magnesium oxide has the potential to be used for flame retardant applications. According to DTG graph as shown in Figure 5(b), the control particleboard sample had the fastest rate of degradation followed by $10 \%$ and $20 \%$ magnesium oxide. This is because as the loading of magnesium oxide increases, the higher temperature is required to degrade the sample. The control sample needed more time and temperature to degrade the components in sample, resulting in the most weight loss.

\subsubsection{LOI}

This analysis was conducted to calculate the minimum percentage oxygen index needed to maintain flaming combustion of flame retardant OPT particleboard under specified laboratory conditions. ${ }^{32}$ Table 3 shows the results of LOI obtained for all the particleboards produced. Based on the findings of a previous study, it had been understood that the greater the amount of oxygen required to burn the 
samples, the greater the flame resistance of the substance. ${ }^{1}$ It also proved that any materials with LOI value greater than $26 \%$ were considered to be flame retarded and the LOI value of at least $28 \%$ would indicate that the materials had good fire resistance capability. ${ }^{1,15}$

Table 3: LOI for all the particleboards produced.

\begin{tabular}{lc}
\hline Particleboard & LOI $(\%)$ \\
\hline Control sample & 25.65 \\
$10 \%$ magnesium oxide & 29.27 \\
$20 \%$ magnesium oxide & 30.81 \\
\hline
\end{tabular}

From Table 3, the OPT particleboard treated with $20 \%$ magnesium oxide had the highest LOI value with $30.81 \%$ followed by particleboard treated with $10 \%$ magnesium oxide with $29.27 \%$ and control sample with $25.65 \%$. It shows that a small amount of magnesium oxide could significantly improve the flame retardant properties of particleboard. All of these might be due to the distribution of flame retardant added and the matrix of particleboard that may affect the mechanism of flame retardant. As the loading of flame retardant increased, the higher oxygen concentrations required to ignite the particleboard.

\section{CONCLUSION}

The physical properties of the oil palm trunk particleboard were not affected by the increased of flame retardant except for thickness swelling, and water absorption which slightly decreased as the percentage of magnesium oxide increased. The mechanical properties of the particleboard decreased as the percentage of flame retardant increased since the deposited magnesium oxide will hinder the interparticle bonding among the particles and the dispersion of urea formaldehyde resin. The addition of magnesium oxide successfully improves the thermal stability and the flame retardant properties of the oil palm trunk particleboard. Based on the findings in this study, the potential of magnesium oxide as flame retarder in OPT particleboard were evaluated.

\section{ACKNOWLEDGEMENTS}

We acknowledge Universiti Sains Malaysia (USM) for the Research University Grant (RU 1001/ PTEKIND/ 814256). We also thank Encore Agricultural Industries Sdn. Bhd., Pahang for providing raw materials and Asta Chemicals, Perai, Penang for providing urea formaldehyde resin to be used in this study. 


\section{REFERENCES}

1. Chin, K. (2014). Mechanical and physical properties of oil palm trunk core particleboard bonded with different UF resins. J. Oil Palm Res., 26(2), 163169.

2. Park, J.-S. \& Lee, J.-J. (2004). Fire resistance of light-framed wood floors exposed to real and standard fire. J. Fire Sci., 22(6), 449-471, https://doi. org/10.1177/0734904104042548.

3. Sulaiman, O. et al. (2012). The potential of oil palm trunk biomass as an alternative source for compressed wood. BioResour., 7(2), 2688-706, https://doi.org/10.15376/biores.7.2.2688-2706.

4. Nagieb, Z. A., Nassar, M. A. \& El-Meligy, M. G. (2011). Effect of addition of boric acid and borax on fire-retardant and mechanical properties of urea formaldehyde saw dust composites. Carbohyd. Chem., 11, 1-6.

5. Malaysian Palm Oil Board. (2012). Overview of the Malaysian oil palm industry 2011. Shah Alam: Economics and Industry Development Division.

6. Abdullah N. \& Sulaiman, F. (2013). The oil palm wastes in Malaysia. In Matovic, M. D. (Ed.). Biomass now-sustainable growth and use. New York: InTech, 75-100.

7. Hamid, S. B. A. et al. (2016). Catalytic isolation and physicochemical properties of nanocrystalline cellulose (NCC) using $\mathrm{HCl}-\mathrm{FeCl} 3$ system combined with ultrasonication. BioResour, 11, 3840-3855, https://doi. org/10.15376/biores.11.2.3840-3855.

8. Hamid, S. B. A., Chowdury, Z. Z. \& Karim, M. Z. (2014). Catalytic extraction of microcrystalline cellulose (MCC) from Elaeis guineensis using central composite design (CCD). BioResour., 9, 7403-7426, https://doi. org/10.15376/biores.9.4.7403-7426.

9. Hamid, S. B. A., Chowdury, Z. Z. \& Zain, S. M. (2014). Base catalytic approach: A promising technique for the activation of biochar for equilibrium sorption studies of copper, $\mathrm{Cu}$ (II) ions in single solute system. Mater, 7, 2815-2832, https://doi.org/10.3390/ma7042815.

10. Chowdury, Z. Z. et al. (2015). Catalytic pretreatment of biochar residues derived from lignocellulosic feedstock for equilibrium studies of manganese, Mn (II) cations from aqueous solution. RSC Adv., 5, 6345-6356, https://doi. org/10.1039/C4RA09709B.

11. Shanghai Xinlongboard Fireproofing Material. (2017). Magnesium oxide board. Retrieved from http://www.xinlongboard.com/products/magnesiumoxide-board.html on 12 April 2017.

12. Kunshan Boda Building Material. (2016). Greenspan magnesium oxide sulfate board. Retrieved from http://www.rockmaxpan.com/GreenspanMagnesium-Oxide-Sulfate-Board-pd763222.html on 12 April 2017. 
13. Pedieu, R. et al. (2012). Fire-retardant properties of wood particleboards treated with boric acid. Eur. J. Wood. Prod., 70(1-3), 191-197, https://doi. org/10.1007/s00107-011-0538-y.

14. Saba, N. et al. (2015). Preparation and characterization of fire retardant nanofiller from oil palm empty fruit bunch fibers. BioResour., 10(3), 4530-4543, https://doi.org/10.15376/biores.10.3.4530-4543.

15. Lebow, S. T. \& Winandy, J. E. (1999). Effect of fire-retardant treatment on plywood $\mathrm{pH}$ and the relationship of $\mathrm{pH}$ to strength properties. Wood Sci. Technol., 33(4), 285-298, https://doi.org/10.1007/s002260050116.

16. JIS. (2003). Japanese Industrial Standard for particle board JIS A 5908. Tokyo: JIS.

17. Segal, L. et al. (1959). An empirical method for estimating the degree of crystallinity of native cellulose using the X-ray diffractometer. Text Res. J., 29(10), 786-794, https://doi.org/10.1177/004051755902901003.

18. Izran, K. et al. (2011). Properties and performance of rubberwood particleboard treated with BP® Fire retardant. J. Sci. Technol., 3(2), 1-7.

19. ISO. (1996). ISO 4589: Determination of burning behavior by oxygen index - Part 2: Ambient temperature test. Geneva: ISO.

20. Aphane M. E. (2009). The hydration of magnesium oxide with different reactivities by water and magnesium acetate. $\mathrm{PhD}$ diss., University of South Africa, Pretoria.

21. Yusoff, M. Z. M., Salit M. S. \& Ismail, N. (2009). Tensile properties of single oil palm empty fruit bunch (OPEFB) fibre. Sains Malays., 38(4), 525-529.

22. Darmawan, W. et al. (2012). The importance of extractives and abrasives in wood materials on the wearing of cutting tools. BioResour., 7, 4715-4729, https://doi.org/10.15376/biores.7.4.4715-4729.

23. Hashim, R. et al. (2009). Physical and mechanical properties of flame retardant urea formaldehyde medium density fiberboard. J. Matt. Process. Tech., 209(2), 635-640, https://doi.org/10.1016/j.jmatprotec.2008.02.036.

24. Tamilselvi, P. et al. (2013). Synthesis of hierarchical structured MgO by solgel method. Nano Bull., 2, 130106.

25. Kashiwagi, T. et al. (2003). Flame-retardant mechanism of silica: Effects of resin molecular weight. J. Appl. Polym. Sci., 87, 1541-1553, https://doi. org/10.1002/app.11967.

26. Ibrahim, M. N. M. et al. (2011). Chemical and thermal properties of lignins from oil palm biomass as a substitute for phenol in a phenol formaldehyde resin production. Carbohydr. Polym., 86(1), 112-119, https://doi.org/ 10.1016/j.carbpol.2011.04.018.

27. Fire Testing Technology. (2007). User's guide for the oxygen index. Part 1: Method 141 and ISO 4589. London: Fire Testing Technology Limited Incorporating Stanton Redcroft. 
28. Fröberg, L. (2016). Thermal analysis TGA/ DTA. Process chemistry centre. Retrieved from http://web.abo.fi/instut/biofuelsGS2/kursen/AA/lectures/ Lectrure_Thermal\%20Analysis.pdf on 15 June 2017.

29. Sonia, A. \& Dasan, K. P. (2013). Chemical, morphology and thermal evaluation of cellulose microfibers obtained from Hibiscus sabdariffa. Carbohydr. Polym., 92(1), 668-674, https://doi.org/10.1016/j.carbpol.2012. 09.015.

30. Dong, Q. et al. (2012). A polycarbonate/magnesium oxide nanocomposite with high flame retardancy. J. Appl. Polym. Sci., 123(2), 1085-1093, https://doi.org/10.1002/app.34574.

31. Tay, G. \& Ong, L. \& Rozman, H. (2012). Mechanical properties and fire retardant behavior of polyurethane foam reinforced with oil palm empty fruit bunch. J. Appl. Polym. Sci., 125(1), 158-164, https://doi.org/10.1002/ app.35568.

32. White, R. H. (1979). Oxygen index evaluation of fire-retardant-treated wood. J. Wood Sci., 12(2), 113-121. 